\title{
STRATEGIC PHILANTHROPY: LITERATURE REVIEW ${ }^{1}$
}

\section{Klára Kubíčková*}

\begin{abstract}
This literature review article aims to facilitate a better understanding of the concept of strategic philanthropy as a controversial topic at the crossroads of business and society. The strategic role of corporate philanthropy has been emphasised by both academics and practitioners and is a topic of long-standing discussion as is the original concept of corporate philanthropy. This article summarises the different definitions, approaches and categorisations that have been adopted by management scholars working in the field of corporate philanthropy and published in the top academic journals. Four main lines of inquiry were distinguished within the literature: the evolution and essence of strategic philanthropy, theoretical foundations of strategic philanthropy, empirical foundations of strategic philanthropy and the measurement of the impact of strategic philanthropy. The results show that the concept of strategic philanthropy is still evolving and different approaches to define and theorise it can be found. The implications for further research are provided at the end of the article.
\end{abstract}

Keywords: strategic philanthropy, corporate philanthropy, share value, impact measurement JEL Classification: M14

\section{Introduction}

The intersection of business and society and the incorporated topic of corporate sustainability have attracted the considerable attention of academics and practitioners in recent years (Montiel, 2008; Sigurthorsson, 2012). Sustainability reporting guidelines (e.g. Global Reporting Initiative (GRI, 2016; IRIS, 2016) or any other standards do not specifically suggest the reporting of philanthropic giving (Chen, Patten and Roberts, 2008; Campbell and Slack, 2008). However, charitable contributions, which have been called the oldest form of corporate social behaviour (Mescon and Tilson, 1987), an outcome of corporate social performance (Wood, 1991; Saiia, Carroll and Buchholtz, 2003) or 'a vital element in corporate citizenship' (Saiia et al., 2003, p. 170), are significantly mentioned in corporate social responsibility reports (Chen et al., 2008).

Corporate philanthropy can be defined as the charitable transfer of corporate resources to recipients at below market prices in the form of direct giving of financial assets as well as in-kind gifts of employee time, goods or services (Block, Glavas, Mannor and Erskine, 2017; Maas and Liket, 2011) or as Ricks and Williams (2005, p. 147) phrase it 'an action when a corporation voluntarily donates a portion of its resources to a societal cause.' In Carroll's model (1979) of corporate social responsibility, a firm's

1 This article was supported by The Internal Grant Agency (IGA) of the University of Economics, Prague under Grant F3/54/2018 The Comparison of Approaches to Measuring the Impact of Philanthropic Activities of Private Companies and Nonprofit Organizations.

* University of Economics, Prague, Faculty of Business Administration (klara.kubickova@vse.cz). 
social responsibilities create a hierarchy of economic, legal, ethical and discretionary responsibilities containing corporate philanthropy as the least important (Seifert, Morris and Bartkus, 2003). Within its discretionary responsibilities, a firm can choose how to voluntarily allocate slack resources to charitable purposes that are not related to the business (Sánchez, 2000), are not mandated, not required by law or generally expected in an ethical sense (Carroll, 2016). In the altruistic model of corporate philanthropy, firms engage in corporate philanthropy with the intent to benefit society without a connection to corporate performance and business gain, thus philanthropy is considered independent from the pressures of generating profit or enhancing image (Sánchez, 2000; Dennis, Buchholtz and Butts, 2009; Cranenburgh and Arenas, 2014). However, pure altruism can hardly be seen as a driving force for corporate philanthropy (Gan, 2006). There are many objectives for corporate giving beyond altruism (Sánchez, 2000; Saiia et al., 2003; Ricks and Williams, 2005; Block et al., 2017) and for many companies, it means more than donations (Bruch and Walter, 2005.) Many companies with a strong sense of corporate social responsibility are moving from traditional charitable giving toward a more strategic, bottom-line approach to philanthropy (Mescon and Tilson, 1987).

Whether corporations should engage in philanthropy at all, for charitable or selfish reasons, is a topic of long-standing discussion (Porter and Kramer, 2002; Gan, 2006). According to the shareholder theory, managers should make decisions that maximise shareholder value (Friedman, 1970; Jensen, 2002; Sundaram and Inkpen, 2004). From this point of view, managers should not give away shareholders' money for purely altruistic reasons because it means stealing from shareholders (Gan, 2006). On the other hand, the stakeholder theory states that managers should take into account the interests of all the stakeholders in the company (Freeman, Wicks and Parmar, 2004; Freeman, 2010). Under this framework, corporate philanthropy is expected from the company as a good corporate citizen (Gan, 2006; Carroll, 2016) who searches for ways to align self-interest with the greater good (Smith, 1994). De Wit and Meyer (2014) consider this conflict as a strategic paradox (profitability vs. responsibility). Thus, managers find themselves in no-win situations between the demands for corporate social responsibility and the pressures to maximise short-term profits (Saiia et al., 2003; Porter and Kramer, 2002). Therefore, companies make charitable donations under profit-maximising constraints (Gan, 2016).

Porter and Kramer (2011) claim that instead of a 'zero-sum game' between the company and its environment, the company can harmonise these interests to create more value for everyone. This is the principle of Porter and Kramer's 'shared value' as well as Emerson's 'blended value' (Emerson, 2003; Emerson and Bonini, 2005). The clear separation between the terms 'doing well' and 'doing good' is disappearing and areas where these approaches are combined as 'do good by doing well' emerge (McGoey, 2014; Epstein, 1989; Seifert et al., 2003). Strategic philanthropy - corporate philanthropy that contributes to a firm's bottom line (Buchholtz, Amason and Rutherford, 1999) - is one these areas (Emerson, Bonini and Brehm, 2003; Emerson and Bonini, 2005).

Strategic philanthropy, situated at the opposite end of the corporate philanthropy spectrum to altruism (Saiia et al., 2003), offers a compromise to the proponents and opponents of corporate philanthropy (Buchholtz et al., 1999; Seifert et al., 2003). According to Windsor (2006), strategic philanthropy should be positioned in Carroll's pyramid between corporate citizenship and economic conception. Dienhart (1988) even argues that charity is consistent with investment. Strategic philanthropy should thus have 
the potential to create win-win opportunities for both the beneficiaries and the company (Bruch and Walter, 2005; Maas and Liket, 2011).

The strategic role of corporate philanthropy has been indicated by academics and practitioners alike (Sánchez, 2000; Bruch and Walter, 2005; Zhang, Zhu, Yue and Zhu, 2010) as CSR's strategic value is supported by a growing body of research (Porter and Kramer, 2006; Husted, Allen and Rivera, 2010; Zhang, Ma, Su and Zhang, 2014; Cantrell, Kyriazis and Noble, 2015; Rangan, Chase and Karim, 2015). The aim of this article is to contribute to this research area by organising the definitions, theories and approaches applied by management scholars in the top research journals into a single article. This article thus summarises the different definitions and approaches that have been adopted in the field of corporate philanthropy and published in these top journals.

\section{Method}

\subsection{Data Collection}

To review the articles related to strategic philanthropy, the literature search by Montinel and Delgado-Ceballos (2014) was used. Their literature search on corporate sustainability was based on the work of Bansal and Gao (2006) who located articles in the organisations and environment area by searching for keywords among the top academic journals in the field of general management. Bansal and Gao's list of journals was expanded by Montiel (2008) by adding organisational behaviour journals, strategy journals and journals devoted to the social issues of management and sustainability. Furthermore, Montinel and DelgadoCeballos (2014) added top practitioner management journals listed in the Fortune Magazine list. The final list of top journals consists of academic management journals: Academy of Management Journal, Academy of Management Review, Administrative Science Quarterly, Organization Science, Journal of Management, Management Science, Journal of International Business Studies, Journal of Management Studies, Organization Studies, British Journal of Management; organisational behaviour journals: Journal of Applied Psychology, Personnel Psychology, Organizational Behavior, Human Decision Processes, Journal of Organizational Behavior; one strategy journal: the Strategic Management Journal; top practitioner management journals: Harvard Business Review, Academy of Management Perspectives, California Management Review, MIT Sloan Management Review and social issues and environmental management journals: Journal of Business Ethics, Business and Society Review, Business Ethics Quarterly, Business \& Society, Organization \& Environment, Business Strategy and the Environment.

The above-mentioned journals were searched for using the term philanthrop* AND strateg* to ensure that the different variations were captured and that the strategic context was included. The search was undertaken using the Business Source Complete database (EBSCO search engine). In total, 39 articles were found to be relevant after reading the abstracts or the whole articles.

\subsection{Data Analysis}

The presentation of the collected articles shows that the concept of strategic philanthropy has been evolving in top academic literature for the last 30 years. As well as with the topic of corporate philanthropy (Gautier and Pache, 2013), it is not until the 1980s that strategic 
philanthropy emerged as a specific research topic captured in the relevant journals (Figure 1).

\section{Figure 1 | Number of relevant articles}

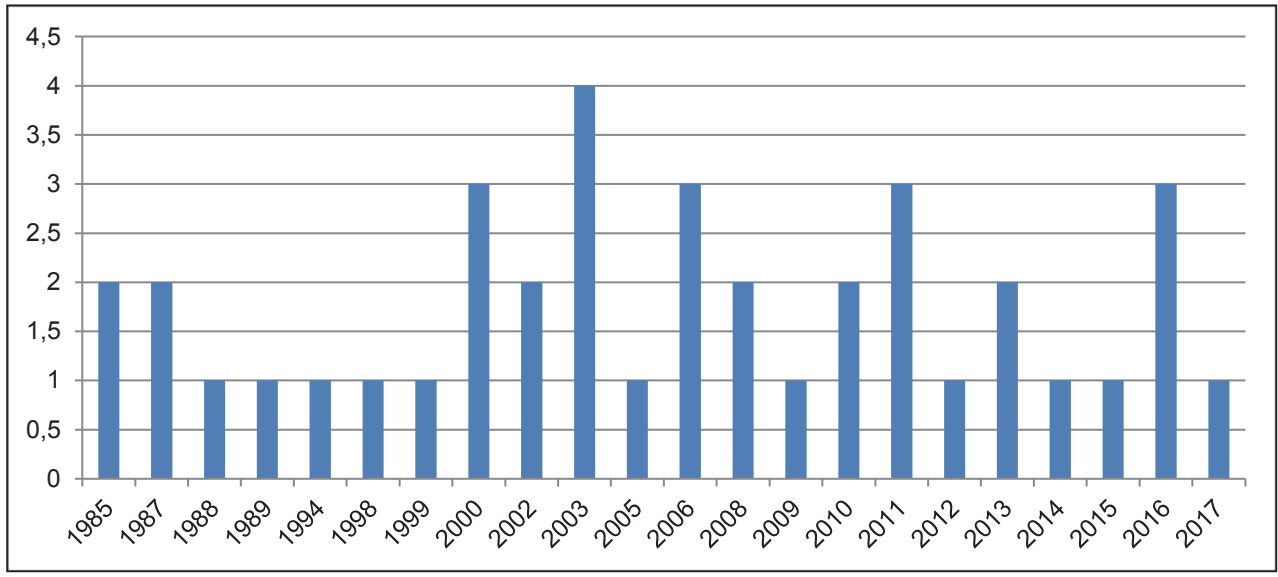

Source: author

Most articles were published in social issues journals, with $41 \%$ of all items in the Journal of Business Ethics, followed by Business \& Society (15\%). Practitioner management journals, with the Harvard Business Review (15\%) and the California Management Review (10\%) at the top, were the second most popular group of journals for this topic. Only two articles were found among the academic management journals (Figure 2).

Figure 2 | Most popular journals for strategic philanthropy research

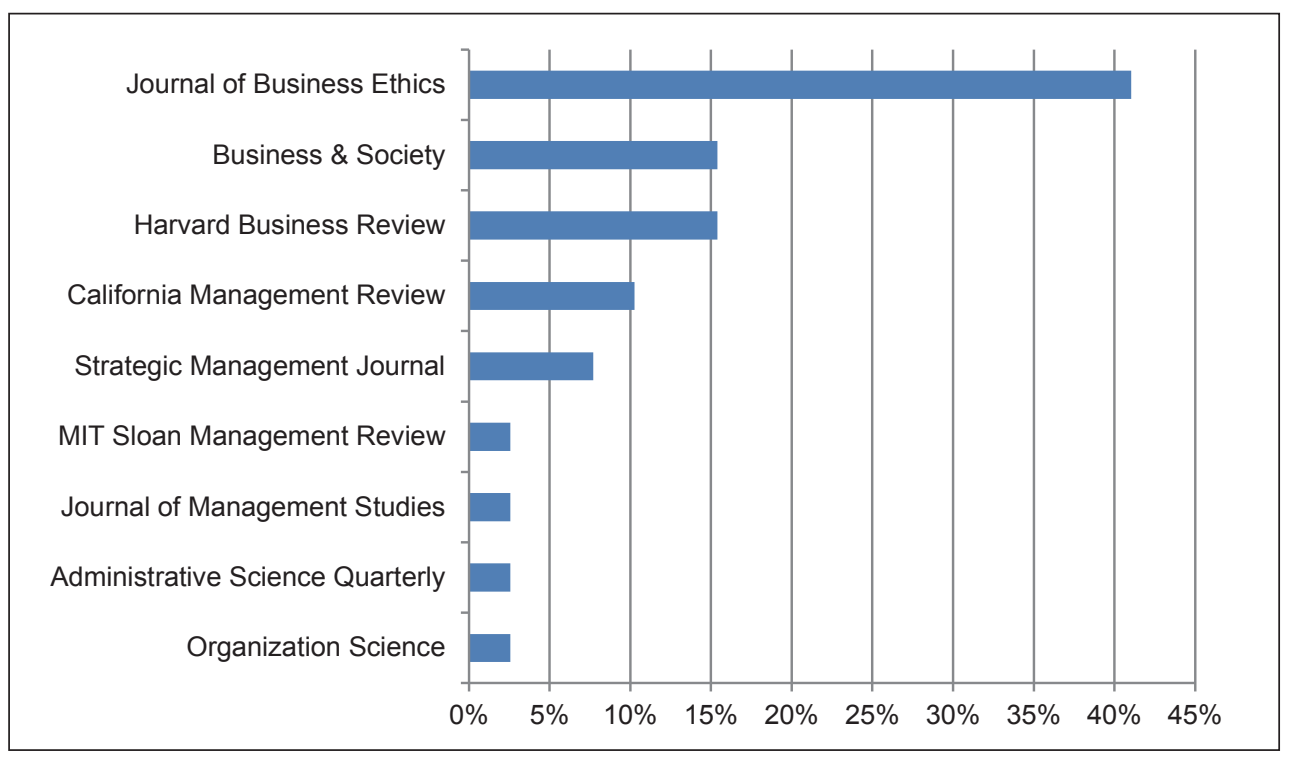




\begin{tabular}{|l|c|}
\hline Journal & $\begin{array}{c}\text { Number } \\
\text { of relevant articles }\end{array}$ \\
\hline Journal of Business Ethics & 16 \\
Business \& Society & 6 \\
Harvard Business Review & 6 \\
California Management Review & 4 \\
Strategic Management Journal & 3 \\
MIT Sloan Management Review & 1 \\
Journal of Management Studies & 1 \\
Administrative Science Quarterly & 1 \\
Organization Science & 1 \\
\hline
\end{tabular}

Source: author

American articles are predictably and by far the largest geographical group with 64\% of articles from authors affiliated in the USA. The results are similar to the findings of Gautier and Pache (2013) in corporate philanthropy. This shows that philanthropy has been (Smith, 1994), and still is, specifically an American preoccupation.

\section{Figure 3 | Country of affiliation of authors}

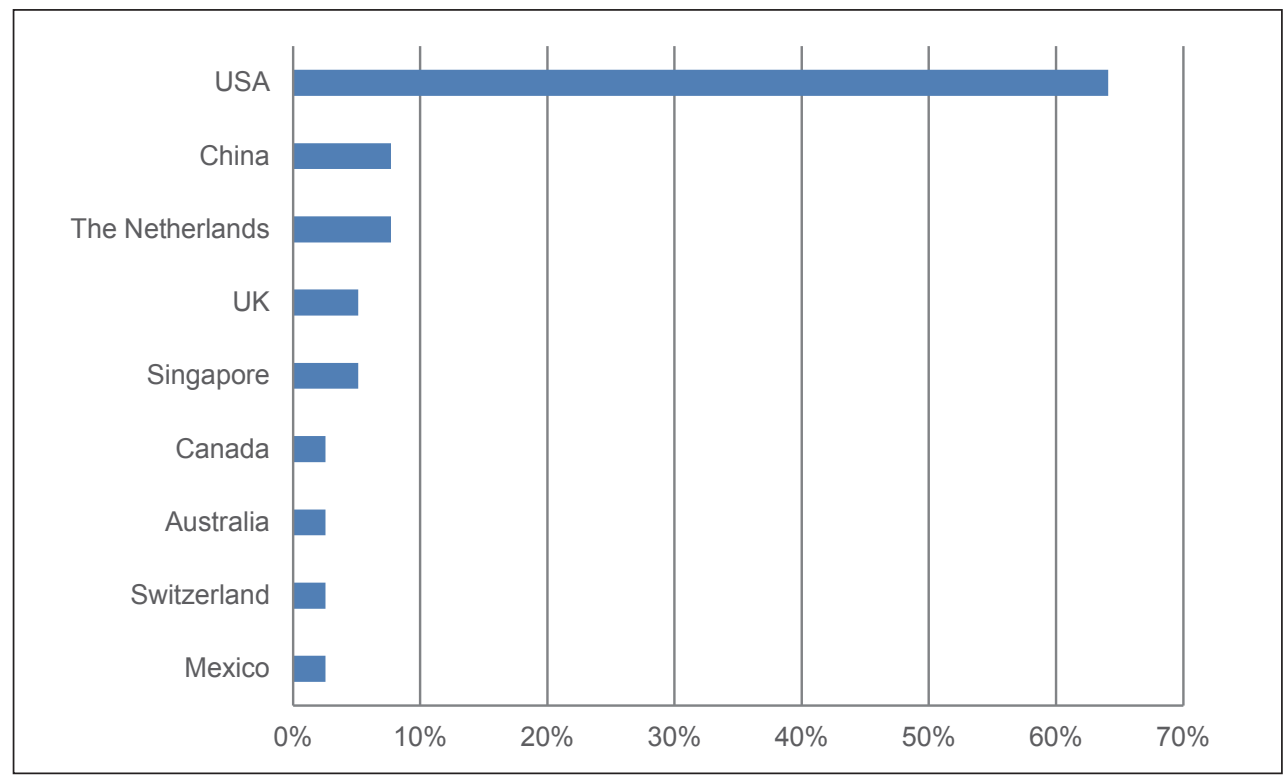

Source: author

Over $50 \%$ of the reviewed literature uses quantitative methods, whereas only $18 \%$ of the methods used are qualitative. A third of all items are theoretical papers without any empirical inquiry. These results are quite similar to those of Gautier and Pache (2013) in their review of corporate philanthropy. 


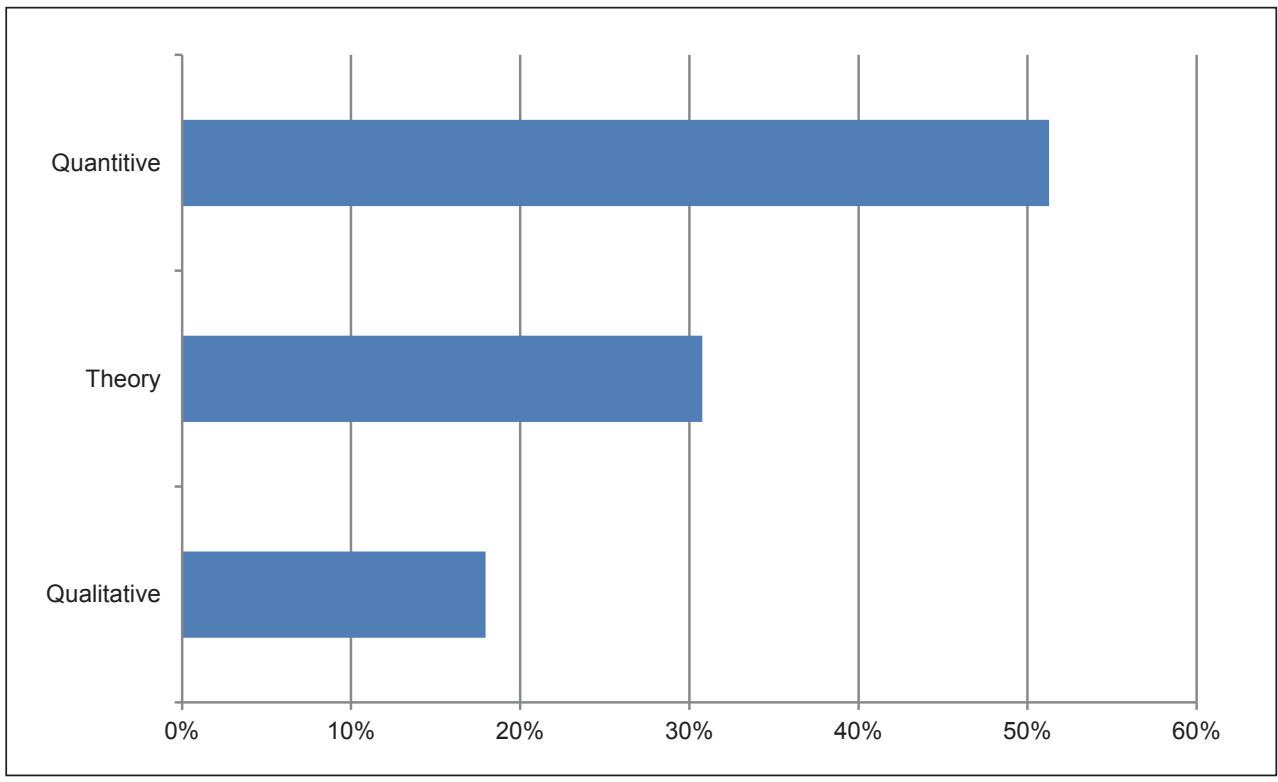

Source: author

As in Gautier and Pache (2013) and Ricks (2012), the main lines of inquiry were distinguished within the literature and the review was grouped into four sections according to the identified findings: the evolution and essence of strategic philanthropy, theoretical foundations of strategic philanthropy, empirical foundations of strategic philanthropy (including the motives, determinants and relationship between CFP and CSP) and the measurement of the impact of strategic philanthropy.

Figure 5 | Proportion of articles by section of identified findings

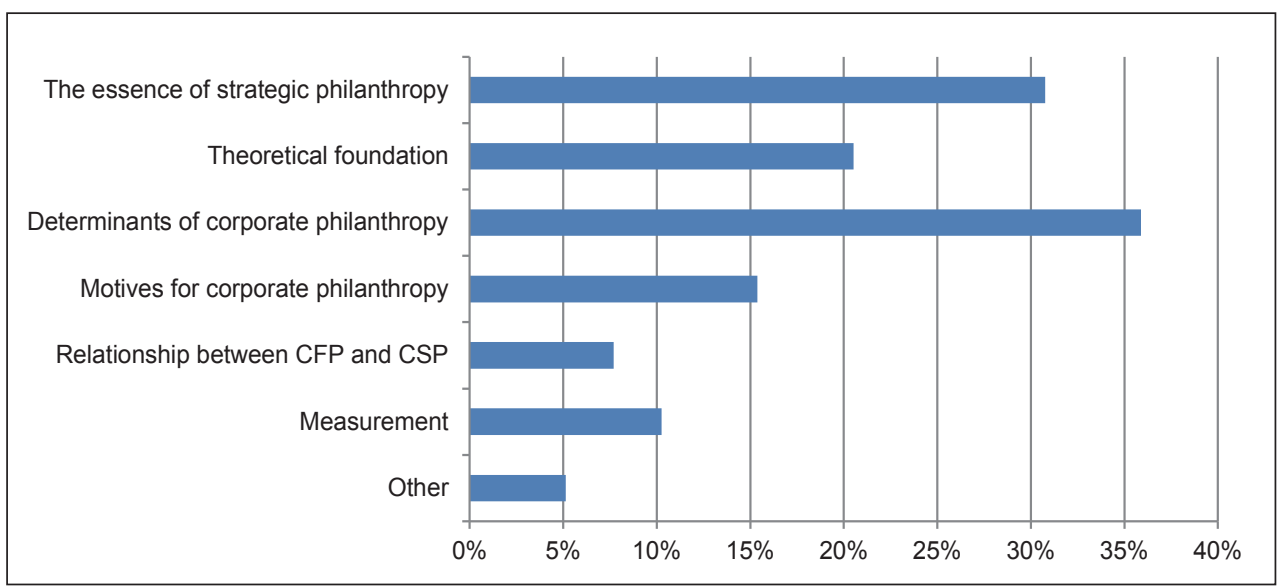

Source: author 


\section{The Evolution and Essence of Strategic Philanthropy}

Being charitable can bring many challenges (Morris and Biederman, 1985). Such actions can win allies, awards and different benefits but also offend other subjects and cause harm to a corporation on several levels (Morris and Biederman, 1985; Dienhart, 1988). An emerging strategy is to manage donations like investments and to expect some type of return (Dienhart, 1988). The debates around the field of corporate philanthropy have thus been more focused on a market-driven, strategic bottom-line approach to philanthropy (Epstein, 1989) where next to the benefits provided to society, the benefits of philanthropy to the firm are also considered (Saiia et al., 2003; Maas and Liket, 2011).

Strategic corporate philanthropy has evolved over the past century (Ricks and Williams, 2005) as one of the motives behind corporate philanthropy, which can be institutional, altruistic, political or strategic (Seifert et al., 2003; Block et al., 2017). Philanthropy, mainly practised by wealthy individuals, has specifically been an American preoccupation (Smith, 1994) and an important part of American society since the 17th century (Ricks and Williams, 2005). Morris and Biederman (1985) see the beginning of corporate philanthropy as the 1870s with donations towards the construction of urban YMCA hotels by the nation's largest railroads because they needed cheap housing for crew members who often finished their workdays far from home. Prior to 1953, when the decision of the Supreme Court in New Jersey decided that corporations are free to donate to charitable purposes, individuals, and not companies, had practised this activity (Morris and Biederman 1985; Dienhart, 1988; Smith, 1994; Ricks and Williams, 2005) and organisations were only allowed to make contributions that were directly related to their shareholders' best interests (Dienhart, 1988; Ricks and Williams, 2005). This industrial style philanthropic approach is based on the argument that a firm's primary responsibility is to increase its shareholders' wealth through increased profits (Ricks and Williams, 2005). Early philanthropic activity was simply not altruistic (Morris and Biederman, 1985).

Since the 1950s, when publicly held companies could donate to nonprofit organisations without direct economic benefit to the shareholders, many companies have taken this principle to the extreme (Morris and Biederman, 1985). Under pressure to demonstrate their social responsibility, most companies established their own foundations (Smith, 1994) and when selecting their causes, corporate donors chose those least associated with their business focus where motives of self-interest could not be seen (Morris and Biederman, 1985; Smith, 1994).

The pressure on organisations to demonstrate their social responsibility brought about the argument for philanthropy as a valid corporate activity for maintaining good relationships with stakeholder groups, which also included the shareholders (Ricks and Williams, 2005). To position philanthropy as a corporate activity, companies began to act on the basis of 'enlightened self-interest' (Morris and Biederman, 1985; Ricks and Williams, 2005). The key premise is the belief that the organisation will benefit from its philanthropic activity in the future through motivated employees or will improve the organisation's brand and that a company cannot survive in a community with social problems. Therefore, through these actions, the organisation is securing its own longterm survival (Ricks and Williams, 2005; Porter and Kramer, 2006). The final attribute of enlightened self-interest is that the benefits were neither immediate, certain, nor 
quantifiable (Ricks and Williams, 2005). However, organisations today are attempting to move beyond enlightened self-interest by tying philanthropic activities into corporate strategy. This linking of philanthropy to strategic business outcomes must be designed to create a measurable benefit in an identifiable time period (Ricks and Williams, 2005; Maas and Liket, 2011). Then it can be called strategic philanthropy.

Table 1 | Definitions of strategic philanthropy

\begin{tabular}{|c|c|c|}
\hline Reference & Term defined & Definition \\
\hline $\begin{array}{l}\text { Saiia et al., 2013, } \\
\text { p. } 170\end{array}$ & Strategic philanthropy & $\begin{array}{l}\text { 'Giving of corporate resources to address } \\
\text { non-business community issues that also benefit } \\
\text { the firm's strategic position and, ultimately, its } \\
\text { bottom line.' } \\
\text { 'An example of a firm seeking to achieve } \\
\text { a synergistic outcome by targeting corporate } \\
\text { resources at societal problems or issues that } \\
\text { resonate with the core values and mission } \\
\text { of the firm.' }\end{array}$ \\
\hline $\begin{array}{l}\text { Ricks } \\
\text { and Williams, } \\
2005 \text {, p. } 149 \text { cite } \\
\text { Ricks, } 2012 \text {, p. } 3\end{array}$ & $\begin{array}{l}\text { Strategic corporate } \\
\text { philanthropy }\end{array}$ & $\begin{array}{l}\text { 'An activity of a firm that involves choosing how } \\
\text { it will voluntarily allocate resources to charitable } \\
\text { or social service activities in order to reach } \\
\text { marketing and other business related objectives } \\
\text { for which there are no clear social expectations as } \\
\text { to how the firm should perform.' }\end{array}$ \\
\hline $\begin{array}{l}\text { Bruch and Walter, } \\
2005, \text { p. } 51\end{array}$ & Strategic philanthropy & $\begin{array}{l}\text { 'A combination of strong external (market) } \\
\text { and internal (competence) orientations. It } \\
\text { balances the needs of beneficiaries with the skills } \\
\text { and competencies of the organization.' }\end{array}$ \\
\hline $\begin{array}{l}\text { Seifert et al., } 2003 \text {, } \\
\text { p. } 199\end{array}$ & Strategic philanthropy & $\begin{array}{l}\text { 'The label that has been used to describe } \\
\text { corporate philanthropy aimed at helping } \\
\text { the bottom line.' }\end{array}$ \\
\hline $\begin{array}{l}\text { Maas and Liket, } \\
2011, \text { p. } 445\end{array}$ & Strategic philanthropy & $\begin{array}{l}\text { 'Strategically motivated giving, where next to } \\
\text { the benefits provided to society, the benefits } \\
\text { of philanthropy to the firm are also considered.' } \\
\text { 'The mixture of...the professionalism in the giving } \\
\text { function, where philanthropy is treated (initiated } \\
\text { and evaluated) with the same rigour as any } \\
\text { other business function, and the match between } \\
\text { the firm's identity and its philanthropy.' }\end{array}$ \\
\hline $\begin{array}{l}\text { Dennis et al., } \\
2009 \text {, p. } 362\end{array}$ & Strategic philanthropy & $\begin{array}{l}\text { 'Philanthropy is a strategic process to the extent } \\
\text { that managers seek to use corporate giving as } \\
\text { an integral part of the firm's strategy.' }\end{array}$ \\
\hline $\begin{array}{l}\text { Dienhart, } 1988 \text {, } \\
\text { p. } 63 \text { cites Morris } \\
\text { and Biederman, } \\
1985, \text { p. } 152\end{array}$ & Charitable investing & $\begin{array}{l}\text { 'The attempt by firms to align their charitable gifts } \\
\text { with their products and goals.' }\end{array}$ \\
\hline
\end{tabular}

Source: author 
According to Hess, Rogovsky and Dunfee (2002), strategic philanthropy was developed in the 1980s based on the theory that 'competing on price and corporate citizenship is smarter than competing on price alone' (Smith, 1994, p. 110; Hess, et al., 2002). Gan (2006) states that the concept of strategic philanthropy entered business and economics literature in 1982 when Fry, Keim and Meiners (1982) found that charitable contributions corresponded positively to the extent of a firm's public contact. Liket and Maas (2016) see the beginning of this concept in the 1990s. The concept of strategic philanthropy may sound like an oxymoron (Saiia et al., 2003) or a contradiction in terms (Gan, 2006) but it is a useful paradox that goes to the heart of the role of business in society (Saiia et al., 2003). Strategic philanthropy is a representative concept of the fact that in an environment with multiple stakeholders with different interests, companies must manage conflicting agendas (Gan, 2016).

Maas and Liket (2011) present the definition of Smith (1996), which consists of five components, where the giving manager should (a) coordinate the giving activities, (b) identify the community issues that align with the core business of the firm, (c) enlist, engage and use the firm's resources in the giving process and (d) push giving activities to all levels and locations of the firm, and where philanthropic activities should be (e) a mission-driven process and (f) regularly evaluated and revised like any other business action.

However, strategic philanthropy should be distinguished from philanthropic strategy. Post and Waddock (1995) were the first to do so (Liket and Maas, 2016). Saiia et al. (2003) view philanthropic strategy as the orderly behaviour of the firm while using the methods and procedures to give money away. Strategic philanthropy then indicates that the charitable contributions have an impact on the firm as well as the community. Campbell and Slack (2008) interpret the philanthropy strategy from the voluntary charitable donations policy disclosures from the annual reports of UK firms as the disclosure describing the intent of how the company disburses its charitable giving. Strategic philanthropy was then signified by the content stating that the motivation behind the philanthropy was to support business strategy or that donations would be made in areas related to the company's core business. The second signifier was evidence from the types of causes supported. In other words, philanthropy strategy focuses only on the systems for donations while strategic philanthropy is about the achievements of these resources on both business and society (Liket and Maas, 2016).

\section{Theoretical Foundations of Strategic Philanthropy}

From the stakeholder theory perspective, corporate citizenship theory and ethical theories, the responsibility of the firm to engage in corporate philanthropy are framed in moral and ethical terms (Dennis et al., 2009; Liket and Maas, 2016). In contrast, the underlying premise of the agency theory is that firms should maximise the wealth of shareholders; therefore, other stakeholders are important only to the extent in which they serve to maximise shareholder wealth (Seifert et al., 2003). This view does not discount all types of philanthropy; it only accepts philanthropic activities that have a positive impact on the bottom line (Dennis et al., 2009). Therefore, according to Campbell and Slack (2008), the case for strategic philanthropy, which is the reconciliation of these opposing views (Liket and Maas, 2016), is very strong from an agency perspective. 
The theoretical foundation of strategic philanthropy can be found in the resource dependency theory and the closely related concept of a resource-based view of the firm (Seifert et al., 2003; Amato and Amato, 2012). Based on the resource dependence theory, which is focused on the availability of critical resources, strategic philanthropy could cut input costs by reducing employee turnover or improving cooperation with the local community (Seifert et al., 2003; Amato and Amato, 2012). According to the resource-based view, charitable contributions have the potential to enhance a firm's specific resources in the form of an improved brand name or reputation and thus contribute to a competitive advantage and increase revenues through customer loyalty (Seifert et al., 2003). When arguing that modern philanthropic and business organisations should join forces and aim to develop charity strategies that provide them with a competitive advantage (Cantrell, Kyriazis, and Noble, 2015; Cranenburgh and Arenas, 2014), Smith (1994) used the concept of Porter and Kramer's shared value (Cranenburgh and Arenas, 2014).

According to the shared value principle (which also has its opponents - e.g. Crane, Palazzo, Spence and Matten, 2014), the mutual dependence of business and society implies that giving choices must benefit both sides (Porter and Kramer, 2002; 2006). If firms make strategically focused philanthropic contributions, social and economic objectives are not separate because these contributions can improve a firm's competitive context while the ability to compete depends on its environment (Porter and Kramer, 2002). This contradicts Friedman's premises (1970). Thus, strategic philanthropy has a dual purpose: to benefit social welfare and financial profitability (Saiia et al., 2013; Maas and Liket, 2011; Liket and Maas, 2016). Although according to Jensen (2002), it is impossible to maximise simultaneously in more than one area because of inherent trade-offs, there is a presumption that - as with other areas where blended or shared values are applied (e.g. social investment or social entrepreneurship) - strategic philanthropy has the potential to achieve a win-win situation (Maas and Liket, 2011). Activities that do not fulfil these two objectives can be easily threatened in difficult economic situations (Bruch and Walter, 2005). Only by creating value for the beneficiaries and simultaneously enhancing the company's business performance, can philanthropic activities become sustainable in the long run (Porter and Kramer, 2002; Bruch and Walter, 2005). The challenges lie in finding innovative ways of achieving both goals (Maas and Liket, 2011). According to Epstein (1989), the key lies in joining donations with marketing efforts, linking giving to special-event sponsorship of sports or artistic events and vigorously publicising such gifts.

Cause-related marketing (e.g. Gourville and Rangan, 2004; Liu and Ko, 2010) was one of the earliest practices known as strategic philanthropy (Mescon and Tilson, 1987; Sánchez, 2000; Porter and Kramer, 2002; Ricks and Williams, 2005); however, the emphasis remains on publicity rather than social impact (Porter and Kramer, 2002). In the framework of strategic philanthropy, organisations enhance the quality of the business environment in their place of business, thus improving their long-term business prospects (Porter and Kramer, 2002). The term strategic philanthropy is thus used in many kinds of charity activities where there is some connection to the focus of the company although this is not a strategic approach, more of a form of advertising.

Sánchez (2000) distinguishes three models of corporate philanthropy - the altruistic model and two strategically motivated models - the profit maximisation model, which is designed to contribute to direct monetary gain (strategic philanthropy) and the political 
and institutional power model. This is also strategically motivated because it maximises benefits, not in the form of an economic return on investment but by benefiting the political environment. Rangan et al. (2015) distinguishes programmes among CSR to those focusing on philanthropy (programmes not designed to produce profits), those improving operational effectiveness (programmes across the value chain reducing resource use, waste, emissions etc.) and those transforming the business (programmes creating new forms of business to address social or environmental challenges while also improving business performance). This is where strategic philanthropy could be positioned according to the definitions above. Research by Bruch and Walter (2005) suggests that philanthropic activities rely on two perspectives - market orientation with the emphasis on the expectations of stakeholders, which brings competitive advantages, such as improved selling capabilities, greater attractiveness as an employer or better relationships with governmental organisations, and competence orientation with the focus on companies' internal abilities and core competencies. Strategic philanthropy is the most effective approach to corporate philanthropy from the four approaches arising from the combination of these perspectives: strategic philanthropy (integrating internal and external perspectives), peripheral philanthropy (mainly driven by external demands and stakeholder expectations), constricted philanthropy (striving for synergies between a company's main activities and their charitable activities) and dispersed philanthropy (largely uncoordinated initiatives increasing the problem of strategic ambiguity, which is the case in the majority of business charity giving programmes (Porter and Kramer, 1999; Porter and Kramer, 2002; Bruch and Walter, 2005; Rangan et al., 2015).

According to Morris and Biederman (1985), managing corporate contributions intelligently means to align gifts with product and goals, put some distance between the endevour for corporate contributions and the CEO, choose the correct organisational structure, choose a manager to allocate company money, treat grant seekers like customers, set a long-term budget for contributions and prepare for opposition. Bruch and Walter (2005) propose tracking the impact, defining exit options, professionalising social engagement and communicating the charitable activities. According to Porter and Kramer (1999), philanthropic activities should rely on the same strategic logic superior performance in the chosen arena as the goal, choosing unique positioning and unique activities and forgoing opportunities in other fields.

\section{Empirical Foundations of Strategic Philanthropy}

Relating the empirical evidence, according to Saiia et al. (2003), corporate giving managers believe that the practice of philanthropy is becoming more strategic. To that end, the strategic motives of corporate giving deserve careful study (Gan, 2006). Campbell and Slack (2008) state that strategic philanthropy has other motives beyond altruism. A great deal of research has considered the motivations of firms engaging in corporate philanthropy (Sánchez, 2000; Brammer and Millington, 2005; Marquis and Lee, 2013; Li, Song and $\mathrm{Wu}, 2015$ ) or which factors influence corporate giving (Atkinson and Galaskiewicz, 1988; Useem, 1988; Lerner and Fryxell, 1994; Bartkus, Morris and Seifert, 2002; Gan, 2006; Dennis et al., 2009; Zhang et al., 2010; Amato and Amato, 2012; Kabongo, Chang and Li, 2012). According to these studies, there are many objectives that can be achieved through strategic corporate philanthropy including 
sales growth (Lev, Petrovits and Radhakrishnan, 2009), improving corporate reputation (Brammer and Millington, 2005), advertising (Zhang et al., 2010) or enhancing customer loyalty and employee commitment (Chen et al., 2008; Block et al., 2017).

Many characteristics influence philanthropic expenditures, such as the attitudes of the CEO or the board composition (Atkinson and Galaskiewicz, 1988; Saiia et al., 2003; Dennis et al., 2009; Marquis and Lee, 2013), company size (Chen et al., 2008; Amato and Amato, 2012), industry (Chen et al., 2008; Amato and Amato, 2012), slack resources (Seifert et al., 2003), business exposure (Saiia et al., 2003) or advertising intensity (Amato and Amato, 2012). Li et al. (2015) found that a firm's political connections positively correlate with the likelihood to donate and the amount of the firm's contributions. Gan (2006) examined whether a corporation's vulnerability to public scrutiny drives its corporate giving, which should, according to him, demonstrate a strategic approach. Cuypers, Koh and Wang (2015) investigated the relationship between corporate philanthropy and company value finding that although innovative (qualitative) and generous (quantitive) corporate philanthropy is positively associated with company value, this positive association is stronger for innovative giving.

However, these empirical studies do not particularly address the principles of strategic philanthropy as stated above. In relation to strategic philanthropy, Seifert et al. (2003) refer to the relationship between corporate philanthropy and a company's financial performance. According to them, the positive relationship between corporate philanthropy and company financial performance, which is enhanced through direct or indirect effects, such as an improved reputation (Ricks and Williams, 2005; Maas and Liket, 2011), would be consistent with the strategic use of philanthropy as well as the fact that tax rates do not affect the level of contributions. However, there are a few empirical studies (Seifert et al., 2003; Brammer and Millington, 2008) that lack clear positive evidence (Bartkus et al., 2002). As Gan (2006) states, there is a lot of descriptive literature on strategic philanthropy stating the strategic rationales behind corporate philanthropy (e.g. Mescon and Tilson, 1987; Porter and Kramer, 2002; Smith, 1994) but without empirical testing. Despite the existing research on the motives behind philanthropic contributions and the determinants of these expenditures, researchers have not focused on the empirical proof of whether companies are engaged in strategic philanthropy or not (Liket and Maas, 2016), leaving it unclear which mechanisms may account for the adoption of philanthropy into business strategies (Marquis and Lee, 2013) and to what extent companies are strategically managing corporate philanthropy (Liket and Maas, 2016). Campbell and Slack (2008) in their study of strategic philanthropy explored voluntary charitable donations policy disclosures from the annual reports with the findings that strategic philanthropy is less in evidence than philanthropy strategy and only a minority of companies show evidence of adopting a fully strategic approach to philanthropy. The empirical study of Liket and Maas (2016) examined the extent to which companies are strategic in their philanthropy through the presence of practices measuring the impact on both business and society. In relation to Smith (1996), Maas and Liket (2011) see the measurement of the impact of philanthropic activities on society and business as a signal of a firm's strategic approach to philanthropy, as does Ricks and Williams (2005). According to these authors, as well as Porter and Kramer (2002), motives and self-proclaimed strategic intentions are not automatically evidence of strategic philanthropy practices. The evidence should be based on the information 
of whether companies measure their business and social impacts simultaneously, which should be a reasonable proxy measure of a company's engagement in strategic philanthropy (Liket and Maas, 2016).

\section{Measurement of the Impact of Strategic Philanthropy}

Evaluation and measurement of success is becoming an important part of contributions programmes, as the significant shift from enlightened self-interest towards strategic philanthropy requires establishing specific and measurable objectives in an identifiable time period (Mescon and Tilson, 1987; Hess et al., 2002; Ricks and Williams, 2005; Rangan, et al., 2015). For the alignment of the dual objectives of strategic philanthropy, it is crucial to measure the impact of philanthropic activities on both social welfare and profit (Maas and Liket, 2011; Liket and Maas, 2016). However, it is possible to measure these impacts and still not act strategically (Liket and Maas, 2016).

As the Rangan et al. (2015) model of CSR distinguishes three groups of programmes, so the impact measurement should be adapted to them. Programmes in the first group (traditional philanthropy) requires measuring nonfinancial outputs while measuring the performance of the second group (programmes improving operational effectiveness) requires tangible approaches that are traditionally captured in annual sustainability reports. Measurement challenges lie within the third group of programmes (new business forms), where a firm must demonstrate social and financial value. According to the definitions above, Maas and Liket (2011; 2016) and Porter and Kramer (2002), strategic philanthropy is neither managing philanthropic activities in an orderly way (Saiia et al., 2003), nor corporate intent to better disburse its charitable giving (Campbell and Slack; 2003) and is not characterised simply by other motives than altruism (Campbell and Slack; 2003). According to this, it can be theoretically understood as the concept of the third group of the Rangar et al., (2015) model. Only by measuring the impact of these activities on business and society can the achievement of the desired results be evaluated and improved (Liket and Maas 2016) and expenditures optimised (Maas and Liket, 2011), as with all management decisions that must be based on the available information (Maas and Liket, 2011). Companies need to develop a measurement system to capture the business impact (for example, by monitoring the impact of the programme on sales to new or existing customers) as well as the social impact (Liket and Maas 2016). However, the value of corporate philanthropy to society remains largely unexplored. For the measurement of the impact on society and reporting for sustainability, the generally accepted principles of accounting and comparable standards do not exist, as they do for the reporting of financial returns (Maas and Liket, 2011).

The integration of social issues in accounting practices and reporting is not novel (Maas and Liket, 2011). Especially in the 1980s and early 1990s, social accounting methods have attracted the attention of academics and practitioners alike (Hess et al., 2002; Maas and Liket, 2011). The requirements to produce measurable indicators for social impact have long been known, as have the specific attempts to standardise these measurements. The existing standards include the Global Reporting Initiative (GRI), the Impact Reporting and Investing Standards (IRIS) developed by the Global Impact Investment Network (GIIN) and the standards of the Institute of Social and Ethical AccountAbility (ISEA) (Hess et al., 2002; Maas and Liket, 2011). Organisations such as Walker Information, 
the Council on Foundations and the London Benchmarking Group are working to develop indicators that will provide management with the relevant information on this area (Hess et al., 2002). Among the innovative methods for impact measurement, the Social Return on Investment (SROI) (e. g. Nicholls, Lawlor, Neitzert and Goodspeed, 2012), which uses monetary expressions while taking into account company interactions with stakeholders, has received major attention (Maas and Liket, 2011).

Of the number of empirical studies on corporate and strategic philanthropy, only a few have addressed whether and what type of impact is measured by firms (Maas and Liket, 2011; Liket and Maas, 2016). Maas and Liket (2011) examined a sample of 500 firms listed in the Dow Jones Sustainability Index (DJSI), to see if firms are strategic in their philanthropy according to the measurement of the impact of their philanthropic activities on society, business, and reputation and stakeholder satisfaction. They concluded that many firms in the DJSI often measure the impact of their philanthropy as the impact on society. Liket and Maas (2016) extended this research by testing a model of strategic philanthropy in which the dependent variable was evidence that a firm does or does not measure the business and social impacts simultaneously. Carrigan (1997), cited by Maas and Liket (2011), conducted an empirical study on UK firms and found that three-quarters of the firms in the sample did not monitor or evaluate their philanthropic work. A huge amount of contributions are thus going out without accounting for what actually becomes of them, or whether the objectives were fulfilled.

Porter and Kramer (2002) state that the most basic premise of a strategy - striving for superior performance - is violated if performance is not measured. Although measuring the impact may be necessary for the concept of strategic philanthropy, particularly the foundations are often ambivalent as to whether funds should be spent on evaluations (Porter and Kramer, 1999). The evaluations at the foundations are often limited to reports on how the money was spent but do not measure social impact, are not objective and are conducted at the single grant level in isolation from other grants.

\section{Conclusion}

For many years, corporate philanthropy was a marginal activity that was executed at the discretion of the CEO (Sánchez, 2000) or the predominant mean through which companies fulfilled social responsibilities to the local communities (Liket and Maas, 2016). The pressures to add value to the bottom line of their organisations forced managers to choose between the demands for corporate social responsibility and short-term profit maximisation (Saiia et al., 2003; Porter and Kramer, 2002). According to Porter and Kramer (2006), leaders in both business and civil society have focused too much on the choice between them instead of focusing on the points of intersection, and they should stop thinking in terms of 'corporate social responsibility' and start thinking in terms of 'corporate social integration.' As the boundaries between public relations, community involvement, corporate social responsibility and marketing become increasingly blurred, philanthropy is becoming more integrated with other firm's activities (Sánchez, 2000) and as global competition requires firms to establish their competitive advantage from various sources (Porter and Kramer, 2002; Hess et al., 2002; Zhang et al., 2010; Cantrell, Kyriazis and Noble, 2015), businesses have increasingly connected their philanthropic 
activities to business strategy, calling it strategic philanthropy (Cranenburgh and Arenas, 2014).

According to Mescon and Tilson (1998), when companies learn how to profit from philanthropy, the survival of the private enterprise system will be ensured. By improving the quality of their environment, corporations will justify their existence in society (Mescon and Tilson, 1987) and also improve their competitive context (Porter and Kramer, 2002). Only philanthropic activities that both create value for society and enhance a company's business performance are thus sustainable in the long term (Bruch and Walter, 2005). To be effective in the long term, corporate contributions must be managed as professionally as the core business activities (Bruch and Walter, 2005). Thus, firms are setting performance objectives and using professional staff to administer charitable donations more effectively (Sánchez, 2000; Mescon and Tilson, 1987) and are actively seeking public awareness of their charitable donations (Mescon and Tilson, 1987; Bruch and Walter, 2005). However, most companies' philanthropic activities still lack a cohesive philanthropic strategy (Porter and Kramer, 1999; Porter and Kramer, 2002; Bruch and Walter, 2005; Rangan et al., 2015) and mainly focus on social welfare and financial profitability simultaneously, which is the requirement of true strategic philanthropy (Saiia et al., 2013; Maas and Liket, 2011; Liket and Maas, 2016; Campbell and Slack 2008).

If the literature on determinants and motives (except the real strategic ones), which some authors do not consider as revealing the true strategic focus of philanthropic activities, is disregarded, then the literature on this topic is quite scarce among the top academic journals.

The concept of strategic philanthropy has been evolving in the top academic literature over the last 30 years but there is still a lack of studies examining whether companies are strategic in their philanthropy. Moreover, most of the studies come from authors affiliated in the USA, which shows that philanthropy has been, and still is, specifically an American preoccupation.

Further research opportunities mainly lie in the field of measuring the impact of strategic philanthropy in relation to the question of whether firms really are strategic in their giving. For this, the research of Campbell and Slack (2008), Maas and Liket (2011) and especially Liket and Maas (2016) appears to be the most important. Their research could be further extended by providing information about the actual measurement practices - which indicators, metrics and methods companies use to evaluate their philanthropic activities and how they collect data.

The theoretical concept of strategic philanthropy is difficult to be verified in practice for the reason of missing methodological tools; however, it still has its meaning. If companies, in an effort to strategically decide on their philanthropic contributions to increase the efficiency of resources spent on philanthropy, both in financial and social terms, begin to evaluate (at least at the basic level) the impact of their philanthropic activities, they can acquire important information from their environment and stakeholders, which can be incorporated into strategic decisions. Subsequently, by examining the tools the organisations use for these evaluations, the factors that influence it and how the results are used from a backward perspective in strategic decision making, it would be possible to develop more effective strategies in this area. 


\section{References}

Amato, L. H. and Amato, C. H. (2012). Retail Philanthropy: Firm Size, Industry, and Business Cycle. Journal of Business Ethics, 107(4), pp. 435-448, https://doi.org/10.1007/s10551-011-1048-x

Atkinson, L. and Galaskiewicz, J. (1988). Stock Ownership and Company Contributions to Charity. Administrative Science Quarterly, 33(1), pp. 82-100, https://doi.org/10.2307/2392856

Bansal, P. and Gao, J. (2006). Building the Future by Looking to the Past: Examining Research Published on Organizations and Environment. Organization \& Environment, 19(4), pp. 458-478, https://doi.org/10.1177/1086026606294957

Bartkus, B. R., Morris, S. A. and Seifert, B. (2002). Governance and Corporate Philanthropy: Restraining Robin Hood? Business \& Society, 41(3), pp. 319-344, https://doi.org/10.1177/000765030204100304

Block, E. S., Glavas, A., Mannor, M. J. and Erskine, L. (2017). Business for Good? An Investigation into the Strategies Firms Use to Maximize the Impact of Financial Corporate Philanthropy on Employee Attitudes. Journal of Business Ethics, 146(1), pp, 167-183, https://doi.org/10.1007/s10551-015-2930-8

Brammer, S. and Millington, A. (2005). Corporate Reputation and Philanthropy: An Empirical Analysis. Journal of Business Ethics, 61(1), pp. 29-44, https://doi.org/10.1007/s10551-005-7443-4

Brammer, S. and Millington, A. (2008). Does It Pay to Be Different? An Analysis of the Relationship Between Corporate Social and Financial Performance. Strategic Management Journal, 29(12), pp. 1325-1343, https://doi.org/10.1002/smj.714

Bruch, H. and Walter, F. (2005). The Keys to Rethinking Corporate Philanthropy. MIT Sloan Management Review, 47(1), pp. 49-55.

Buchholtz, A. K., Amason, A. C. and Rutherford, M. A. (1999). Beyond Resources: The Mediating Effect of Top Management Discretion and Values on Corporate Philanthropy. Business \& Society, 38(2), pp. 167-187, https://doi.org/10.1177/000765039903800203

Campbell, D. and Slack, R. (2008). Corporate 'Philanthropy Strategy' and 'Strategic Philanthropy': Some Insights from Voluntary Disclosures in Annual Reports. Business \& Society, 47(2), pp. 187-212, https://doi.org/10.1177/0007650306297941

Cantrell, J. E., Kyriazis, E. and Noble, G. (2015). Developing CSR Giving as a Dynamic Capability for Salient Stakeholder Management. Journal of Business Ethics, 130(2), pp. 403-421, https://doi.org/10.1007/s10551-014-2229-1

Carroll, A. B. (1979). A Three-Dimensional Conceptual Model of Corporate Performance. Academy of Management Review, 4(4), pp. 497-505, https://doi.org/10.5465/AMR.1979.4498296

Carroll, A. (2016). Carroll's Pyramid of CSR: Taking Another Look. International Journal of Corporate Social Responsibility, 1(1), https://doi.org/10.1186/s40991-016-0004-6

Carrigan, M. (1997). The Great Corporate Giveaway - Can Marketing Do Good for the 'Do-Gooders'? European Business Journal, 9(4), pp. 40-46.

Chen, J. C., Patten, D. M. and Roberts, R. W. (2008). Corporate Charitable Contributions: A Corporate Social Performance or Legitimacy Strategy? Journal of Business Ethics, 82(1), pp. 131-144, https://doi.org/10.1007/s10551-007-9567-1 
Crane, A., Palazzo, G., Spence and L. J., Matten, D. (2014). Contesting the Value of 'Creating Shared Value'. California Management Review, 56(2), pp. 130-153, https://doi.org/10.1525/cmr.2014.56.2.130

Cranenburgh, K. C. V. and Arenas, D. (2014). Strategic and Moral Dilemmas of Corporate Philanthropy in Developing Countries: Heineken in Sub-Saharan Africa. Journal of Business Ethics, 122(3), pp. 523-536, https://doi.org/10.1007/s10551-013-1776-1

Cuypers, I. R. P., Koh, P.-S. and Wang, H. (2015). Sincerity in Corporate Philanthropy, Stakeholder Perceptions and Firm Value. Organization Science, 27(1), pp. 173-188, https://doi.org/10.1287/orsc.2015.1030

Dennis, B. S., Buchholtz, A. K. and Butts, M. M. (2009). The Nature of Giving: A Theory of Planned Behavior Examination of Corporate Philanthropy. Business \& Society, 48(3), pp. 360-384, https://doi.org/10.1177/0007650307305368

De Wit, B. and Meyer, R. (2014). Strategy: Process, Content, Context - An International Perspective. Andover, UK: Cengage Learning EMEA.

Dienhart, J. W. (1988). Charitable Investments: A Strategy for Improving the Business Environment. Journal of Business Ethics, 7(1-2), pp. 63-71, https://doi.org/10.1007/BF00381999

Emerson, J. (2003). The Blended Value Proposition: Integrating Social and Financial Returns. California Management Review, 45(4), pp. 35-51, https://doi.org/10.2307/41166187

Emerson, J. and Bonini, S. (2005). Maximizing Blended Value-Building Beyond the Blended Value Map to Sustainable Investing, Philanthropy and Organizations, [online]. Available at: http://www.blendedvalue.org/wp-content/uploads/2004/02/pdf-max-blendedvalue.pdf [Accessed 18 Jun. 2017]

Emerson, J., Bonini, S. and Brehm, K. (2003). The Blended Value Map: Tracking the Intersects and Opportunities of Economic, Social and Environmental Value Creation, [online]. Available at: http://www.blendedvalue.org/wp-content/uploads/2004/02/pdf-bv-map.pdf [Accessed 18 Jun. 2017]

Epstein, E. M. (1989). Business Ethics, Corporate Good Citizenship and the Corporate Social Policy Process: A View from the United States. Journal of Business Ethics, 8(8), pp. 583-595, https://doi.org/10.1007/BF00383027

Freeman, R. E. (2010). Managing for Stakeholders: Trade-Offs or Value Creation. Journal of Business Ethics, 96(S1), pp. 7-9, https://doi.org/10.1007/s10551-011-0935-5

Freeman, R. E., Wicks, A. C. and Parmar, B. (2004). Stakeholder Theory and 'The Corporate Objective Revisited'. Organization Science, 15(3), pp. 364-369, https://doi.org/10.1287/orsc.1040.0066

Friedman, M. (1970). The Social Responsibility of Business is to Increase its Profits. The New York Times Magazine, [online]. Available at:

http://www.colorado.edu/studentgroups/libertarians/issues/friedman-soc-resp-business. html [Accessed 18 Jun. 2017]

Fry, L. W., Keim, G. D. and Meiners, R. E. (1982). Corporate Contributions: Altruistic or For-Profit? The Academy of Management Journal, 25(1), pp. 94-106, https://doi.org/10.2307/256026

Gan, A. (2006). The Impact of Public Scrutiny on Corporate Philanthropy. Journal of Business Ethics, 69(3), pp. 217-236, https://doi.org/10.1007/s10551-006-9087-4

Gautier, A. and Pache, A.-C. (2015). Research on Corporate Philanthropy: A Review and Assessment. Journal of Business Ethics, 126(3), pp. 343-369, https://doi.org/10.1007/s10551-013-1969-7 
Gourville, J. T. and Rangan, V. K. (2004). Valuing the Cause Marketing Relationship. California Management Review, 47(1), pp. 38-57, https://doi.org/10.2307/41166286

GRI (Global Reporting Initiative), (2016). GRI Sustainability Reporting Standards, [online]. Globalreporting.org. Available at: https://www.globalreporting.org/standards [Accessed 23 Apr. 2018]

IRIS (Impact Reporting and Investing Standards), (2016). Social Impact Objectives (OD6247), [online]. Available at : https://iris.thegiin.org/metric/4.0/OD6247 [Accessed 23 Apr. 2018]

Hess, D., Rogovsky, N. and Dunfee, T. W. (2002). The Next Wave of Corporate Community Involvement: Corporate Social Initiatives. California Management Review, 44(2), pp. 110-125, https://doi.org/10.2307/41166125

Husted, B. W., Allen, D. B. and Rivera, J. E. (2010). Governance Choice for Strategic Corporate Social Responsibility: Evidence From Central America. Business \& Society, 49(2), pp. 201-215, https://doi.org/10.1177/0007650308315504

Jensen, M. C. (2002). Value Maximization, Stakeholder Theory, and the Corporate Objective Function. Business Ethics Quarterly, 12(2), pp. 235, https://doi.org/10.2307/3857812

Kabongo, J. D., Chang, K. and Li, Y. (2013). The Impact of Operational Diversity on Corporate Philanthropy: An Empirical Study of U.S. Companies. Journal of Business Ethics, 116(1), pp. 49-65, https://doi.org/10.1007/s10551-012-1445-9

Lerner, L. D. and Fryxell, G. E. (1994). CEO Stakeholder Attitudes and Corporate Social Activity in the Fortune 500. Business \& Society, 33(1), pp. 58-81, https://doi.org/10.1177/000765039403300104

Lev, B., Petrovits, Ch. and Radhakrishnan, S. (2009). Is Doing Good Good for You? How Corporate Charitable Contributions Enhance Revenue Growth. Strategic Management Journal, 31(2), pp. 182-200, https://doi.org/10.1002/smj.810

Li, S., Song, X. and Wu, H. (2015). Political Connection, Ownership Structure, and Corporate Philanthropy in China: A Strategic-Political Perspective. Journal of Business Ethics, 129(2), pp. 399-411, https://doi.org/10.1007/s10551-014-2167-y

Liket, K. and Maas, K. (2016). Strategic Philanthropy: Corporate Measurement of Philanthropic Impacts as a Requirement for a 'Happy Marriage' of Business and Society. Business \& Society, 55(6), pp. 889-921, https://doi.org/10.1177/0007650314565356

Liu, G. and Ko, W.-W. (2011). An Analysis of Cause-Related Marketing Implementation Strategies Through Social Alliance: Partnership Conditions and Strategic Objectives. Journal of Business Ethics, 100(2), pp. 253-281, https://doi.org/10.1007/s10551-010-0679-7

Maas, K. and Liket, K. (2011). Talk the Walk: Measuring the Impact of Strategic Philanthropy. Journal of Business Ethics, 100(3), pp. 445-464, https://doi.org/10.1007/s10551-010-0690-z

Marquis, C. and Lee, M. (2013). Who Is Governing Whom? Executives, Governance, and the Structure of Generosity in Large U.S. Firms. Strategic Management Journal, 34, pp. 483-497, https://doi.org/10.1002/smj.2028

McGoey, L. (2014). The Philanthropic State: Market-State Hybrids in the Philanthrocapitalist Turn. Third World Quarterly, 35(1), pp. 109-125, https://doi.org/10.1080/01436597.2014.868989

Mescon, T. S. and Tilson, D. J. (1987). Corporate Philanthropy: A Strategic Approach to the Bottom-Line. California Management Review, 29(2), pp. 49-61, https://doi.org/10.2307/41165238 
Montiel, I. (2008). Corporate Social Responsibility and Corporate Sustainability: Separate Pasts, Common Futures. Organization \& Environment, 21(3), pp. 245-269, https://doi.org/10.1177/1086026608321329

Montiel, I. and Delgado-Ceballos, J. (2014). Defining and Measuring Corporate Sustainability: Are We There Yet? Organization \& Environment, 27(2), pp. 113-139, https://doi.org/10.1177/1086026614526413

Morris, R. I. and Biederman, D. A. (1985). How to Give Money Intelligently. Harvard Business Review, 63(6), pp. 151-159.

Nicholls, J., Lawlor, E., Neitzert, E. and Goodspeed, T. (2012). A Guide to Social Return on Investment, [online]. Available at: http://socialvalueint.org/wp-content/uploads/2016/12/ The-SROI-Guide-2012.pdf [Accessed 3 Aug. 2017]

Porter, M. E. and Kramer, M. R. (1999). Philanthropy's New Agenda: Creating Value. Harvard Business Review, 77(6), pp. 121-130.

Porter, M. E. and Kramer, M. R. (2002). The Competitive Advantage of Corporate Philanthropy, [online]. Harvard Business Review. Available at: https://hbr.org/2002/12/the-competitiveadvantage-of-corporate-philanthropy [Accessed 12 Mar. 2017]

Porter, M. E. and Kramer, M. R. (2006). Strategy and Society: The Link Between Competitive Advantage and Corporate Social Responsibility, [online]. Harvard Business Review. Available at: https://hbr.org/2006/12/strategy-and-society-the-link-between-competitiveadvantage-and-corporate-social-responsibility [Accessed 12 Mar. 2015]

Porter, M. E. and Kramer, M. R. (2011). The Big Idea: Creating Shared Value. How to Reinvent Capitalism - and Unleash a Wave of Innovation and Growth, [online]. Available at: http://www.academia.edu/12407876/HBR.ORG_The_Big_Idea_Creating_Shared_Value_ How_to_reinvent_capitalism_and_unleash_a_wave_of_innovation_and_growth_by_ Michael_E._Porter_and [Accessed 16 Aug. 2017]

Post, J. E. and Waddock, S. A. (1995). Strategic Philanthropy and Partnerships for Economic Progress, Philanthropy and Economic Development. In R. F. America, Philanthropy and Economic Development, pp. 167-191. Westport, CT: Greenwood Press.

Rangan, V. K., Chase, L. and Karim, S. (2015). The Truth About CSR. Harvard Business Review, [online]. Available at: https://hbr.org/2015/01/the-truth-about-csr [Accessed 12 Mar. 2018]

Ricks, J. M. and Williams, J. A. (2005). Strategic Corporate Philanthropy: Addressing Frontline Talent Needs Through an Educational Giving Program. Journal of Business Ethics, 60(2), pp. 147-157, https://doi.org/10.1007/s10551-005-1175-3

Ricks, J. M. 2012. The Effects of Strategic Corporate Philanthropy on Consumer Perceptions, [online]. Available at: https://digitalcommons.Isu.edu/cgi/viewcontent. cgi?article $=2166 \&$ context=gradschool_dissertations [Accessed 18 Mar. 2018]

Saiia, D. H., Carroll, A. B. and Buchholtz, A. K. (2003). Philanthropy as Strategy: When Corporate Charity 'Begins at Home'. Business \& Society, 42(2), pp. 169-201, https://doi.org/10.1177/0007650303042002002

Sánchez, C. M. (2000). Motives for Corporate Philanthropy in El Salvador: Altruism and Political Legitimacy. Journal of Business Ethics, 27(4), pp. 363-375, https://doi.org/10.1023/A:1006169005234

Seifert, B., Morris, S. A. and Bartkus, B. R. (2003). Comparing Big Givers and Small Givers: Financial Correlates of Corporate Philanthropy. Journal of Business Ethics, 45(3), pp. 195-211, https://doi.org/10.1023/A:1024199411807 
Sigurthorsson, D. (2012). The Icelandic Banking Crisis: A Reason to Rethink CSR? Journal of Business Ethics, 111(2), pp. 147-156, https://doi.org/10.1007/s10551-012-1207-8

Smith, N. C. (1994). The New Corporate Philanthropy. Harvard Business Review, [online]. Available at:https://hbr.org/1994/05/the-new-corporate-philanthropy [Accessed 12 Mar. 2018]

Smith, C. (1996). Desperately Seeking Data: Why Research is Crucial to New Corporate Philanthropy. In D. F. Burlingame, Corporate Philanthropy at the Crossroads, pp. 1-6. Bloomington: Indiana University Press.

Sundaram, A. K. and Inkpen, A. C. (2004). Stakeholder Theory and 'The Corporate Objective Revisited': A Reply. Organization Science, 15(3), pp. 370-371, https://doi.org/10.1287/orsc.1040.0067

Useem, M. (1988). Market and Institutional Factors in Corporate Contributions. California Management Review, 30(2), pp. 77-88, https://doi.org/10.2307/41166548

Windsor, D. (2006). Corporate Social Responsibility: Three Key Approaches. Journal of Management Studies, 43(1), pp. 93-114, https://doi.org/10.1111/j.1467-6486.2006.00584.x

Wood, D. J. (1991). Corporate Social Performance Revisited. The Academy of Management Review, 16(4), pp. 691-718, https://doi.org/10.2307/258977

Zhang, R., Zhu, J., Yue, H. and Zhu, C. (2010). Corporate Philanthropic Giving, Advertising Intensity, and Industry Competition Level. Journal of Business Ethics, 94(1), pp. 39-52, https://doi.org/10.1007/s10551-009-0248-0

Zhang, M., Ma, L., Su, J. and Zhang, W. (2014). Do Suppliers Applaud Corporate Social Performance? Journal of Business Ethics, 121(4), pp. 543-557, https://doi.org/10.1007/s10551-013-1735-x 